\title{
Integrated production of cellulosic bioethanol and succinic acid from rapeseed straw after dilute-acid pretreatment
}

Kuglarz, Mariusz; Alvarado-Morales, Merlin; Dbkowska, Katarzyna; Angelidaki, Irini

Published in:

Bioresource Technology

Link to article, DOI:

10.1016/j.biortech.2018.05.099

Publication date:

2018

Document Version

Peer reviewed version

Link back to DTU Orbit

Citation (APA):

Kuglarz, M., Alvarado-Morales, M., Dbkowska, K., \& Angelidaki, I. (2018). Integrated production of cellulosic bioethanol and succinic acid from rapeseed straw after dilute-acid pretreatment. Bioresource Technology, 265, 191-199. https://doi.org/10.1016/j.biortech.2018.05.099

\section{General rights}

Copyright and moral rights for the publications made accessible in the public portal are retained by the authors and/or other copyright owners and it is a condition of accessing publications that users recognise and abide by the legal requirements associated with these rights.

- Users may download and print one copy of any publication from the public portal for the purpose of private study or research.

- You may not further distribute the material or use it for any profit-making activity or commercial gain

- You may freely distribute the URL identifying the publication in the public portal 


\section{Accepted Manuscript}

Integrated production of cellulosic bioethanol and succinic acid from rapeseed straw after dilute-acid pretreatment

Mariusz Kuglarz, Merlin Alvarado-Morales, Katarzyna Dąbkowska, Irini Angelidaki

PII:

DOI:

Reference:

To appear in:

Received Date:

Revised Date:

Accepted Date:
S0960-8524(18)30767-3

https://doi.org/10.1016/j.biortech.2018.05.099

BITE 20005

Bioresource Technology

27 May 2018

28 May 2018

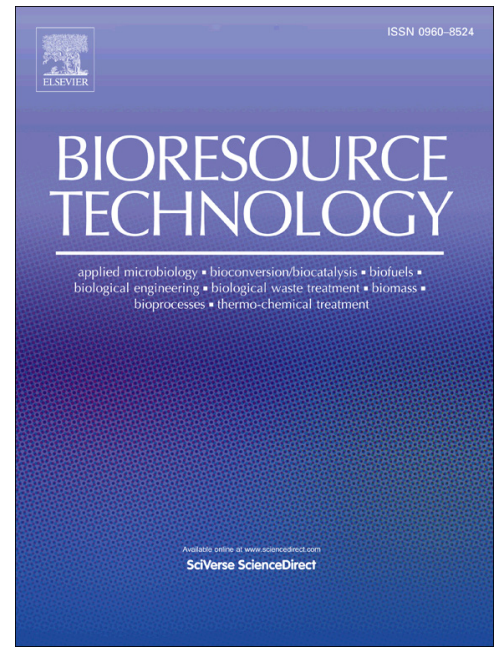

Please cite this article as: Kuglarz, M., Alvarado-Morales, M., Dąbkowska, K., Angelidaki, I., Integrated production of cellulosic bioethanol and succinic acid from rapeseed straw after dilute-acid pretreatment, Bioresource Technology (2018), doi: https://doi.org/10.1016/j.biortech.2018.05.099

This is a PDF file of an unedited manuscript that has been accepted for publication. As a service to our customers we are providing this early version of the manuscript. The manuscript will undergo copyediting, typesetting, and review of the resulting proof before it is published in its final form. Please note that during the production process errors may be discovered which could affect the content, and all legal disclaimers that apply to the journal pertain. 
Integrated production of cellulosic bioethanol and succinic acid from rapeseed straw after dilute-acid pretreatment

Mariusz Kuglarz ${ }^{\mathrm{a}}$, Merlin Alvarado-Morales ${ }^{\mathrm{b}}$, Katarzyna Dąbkowska ${ }^{\mathrm{c}}$, Irini Angelidaki ${ }^{\mathrm{b}} *$

${ }^{\mathrm{a}}$ Faculty of Materials, Civil and Environmental Engineering, University of Bielsko-

Biala, Willowa 2, Bielsko-Biala, Poland

${ }^{b}$ Department of Environmental Engineering, Technical University of Denmark,

Building 113, DK-2800 Lyngby, Denmark

${ }^{c}$ Faculty of Chemical and Process Engineering, Warsaw University of Technology, 00645 Warsaw, ul. Waryńskiego 1, Poland

*Corresponding author. Tel: +45 4525 1429; fax: +45 4593 2850. E-mail: iria@env.dtu.dk (I. Angelidaki) 
ABSTRACT: The aim of this study was to develop an integrated biofuel (cellulosic bioethanol) and biochemical (succinic acid) production process from rapeseed straw after dilute-acid pretreatment. Rapeseed straw pretreatment at 20\% (w/v) solid loading and subsequent hydrolysis with Cellic ${ }^{\circledR}$ CTec2 resulted in high glucose yield (80\%) and ethanol output (122-125 kg of EtOH/Mg of rapeseed straw). Supplementation the enzymatic process with $10 \%$ dosage of endoxylanases $\left(\right.$ Cellic $\left.{ }^{\circledR} \mathrm{HTec} 2\right)$ reduced the hydrolysis time required to achieve the maximum glucan conversion by $44-46 \%$ and increased the xylose yield by $10 \%$ compared to the process with Cellic ${ }^{\circledR}$ CTec2. Significantly higher amounts of succinic acid were produced after fermentation of pretreatment liquor (48 kg/Mg of rapeseed straw, succinic acid yield: $60 \%$ ) compared to fermentation of xylose-rich residue after ethanol production $(35-37 \mathrm{~kg} / \mathrm{Mg}$ of rapeseed straw, succinic yield: $68-71 \%$ ). Results obtained in this study clearly proved the biorefinery potential of rapeseed straw.

Keywords: Cellulosic bioethanol, Succinic acid, Straw, Dilute-acid pretreatment, Cellic ${ }^{\circledR}$ CTec2 


\section{Introduction}

Rapeseed has traditionally been grown for the production of vegetable oils and/or animal feed. In the last years, more and more rapeseed oil has been used as feedstock for biodiesel production. Producing biodiesel as the only biofuel from rapeseed is not considered as the most sustainable conversion route; as the recovered oilseeds represent less than $33 \%$ of the biomass obtained in the field (Boldrin et al., 2013). The usage of rapeseed straw, which constitutes more than $40 \%$ of the whole rape plant dry matter, is highly recommended. Alternative uses of rapeseed include: biochar production, gasification as well as biotechnological production of biofuels (biogas, bioethanol, biohydrogen) and chemicals (acetic acid, furfural, or 5-hydroxymethylfurfural) (Jeong et al., 2010, Luo et al., 2011). Up to now, rapeseed straw was also used for effective ethanol production $(0.15 \mathrm{~g}$ ethanol/g dry straw after combined alkaline peroxide and steam pretreatment) in a biorefinery concept. In this scenario, by-products generated during biomass processing (pretreatment liquor and thin stillage) were evaluated for hydrogen and methane production (Luo et al., 2011). Nowadays, production of succinic acid from lignocellulosic residues through microbial fermentation has gained worldwide attention. Bio-succinic production can contribute to the abatement of $\mathrm{CO}_{2}$ emissions as this gas is consumed during succinic acid fermentation (Pateraki et al., 2016). However, an effective and cost-efficient production of biofuels and/or bio-products from biomass is strictly connected with the amount of sugars released during pre-treatment and/or subsequent enzymatic hydrolysis. Among various pretreatment methods, steam treatment facilitated by acid-addition, is considered as one of the most promising methods for altering the structure of lignocellulosic materials. In this case, sulfuric acid $(\leq 2 \%(\mathrm{w} / \mathrm{v}))$ is usually used as an effective catalyst (Lu et al., 2009, Mathew et al., 
2011, Talebnia et al., 2015). In most cases, about 10\% (w/v) biomass loading is considered as the optimal and/or the studies do not consider biomass loadings above 10\% (w/v) (Mathew et al., 2011, Talebnia et al., 2015). It is still not completely clear if the loading of rapeseed straw can be higher than $10 \%$ during pre-treatment with sulfuric acid, assuming high process effectiveness and minimal sugar losses. Higher biomass loading during pretreatment is more beneficial due to reduced size of equipment and lower energy consumption for processing a unit mass of biomass. It has also a positive effect on the separation costs provided that the solid and liquid fractions, after pretreatment, are used for different conversion purposes (Sindhu et al., 2011, Luterbacher et al., 2012, Cannella and Jorgensen, 2014). The pre-treated material usually undergoes enzymatic hydrolysis, in order to obtain fermentable sugars. During last few years, Celluclast ${ }^{\circledR} 1.5 \mathrm{~L}$ derived from Trichoderma reesei supplemented by Novozyme 188 containing $\beta$-glucosidases from A. niger were the classical and one of the most frequently used enzyme cocktails for different types of lignocellulosic biomasses, including studies on rapeseed straw. Until now, newer generation enzymes with higher specific cellulosic activity and enhanced resistance towards inhibitors (e.g. Novozymes Cellic ${ }^{\circledR} \mathrm{CTec} 2$ ) have only been applied for limited range of lignocellulosic materials, including: switchgrass, wheat straw, sugarcane bagasse and corn stover (Haven and Jorgensen, 2013, Tai and Keshwani, 2014). There has been an enormous focus on second generation bioethanol produced from lignocellulosic materials in the recent years. However, economically competitive production of lignocellulosic ethanol on a commercial scale still remains a challenge. Integrated production of lignocellulosic bioethanol and succinic acid can constitute a valuable solution. This would allow an 
effective conversion of all fermentable sugars and utilization of carbon dioxide, which is a stoichiometric by-product of bio-ethanol production.

This study presents an integrated ethanol and succinic acid production from rapeseed straw, after dilute-acid $\left(1 \% \mathrm{H}_{2} \mathrm{SO}_{4}\right)$ pretreatment method. The aim of this study was also to analyze the influence of biomass loading on the effectiveness of dilute-acid pretreatment. The biomass after pretreatment was enzymatically hydrolyzed and the aim of this part of the study was to establish the optimal combination of newer generation cellulase $\left(\right.$ Cellic ${ }^{\circledR}$ CTec2) and hemicellulase (Cellic ${ }^{\circledR}$ HTec2) cocktails. Application of Novozymes Cellic ${ }^{\circledR}$ CTec2 cocktails for the hydrolysis of rapeseed straw, especially after dilute-acid pretreatment at high solid loading and for combined production of ethanol and succinic acid, has never been reported. The biomass pretreated was converted into ethanol, using ordinary baker's yeast, Saccharomyces cerevisiae. Non-engineered yeasts can only convert C6 sugars into ethanol, and the ethanol fermentation of C5 sugars from hemicellulosic fraction still remains a challenge due to low conversions yields (Kricka et al., 2015). In this study, by-products rich in xylose (pretreatment liquor and residues after ethanol production) were used as feedstock for bio-succinic acid production, using Actinobacillus succinogenes 130Z. According to best of our knowledge, this is the first study evaluating integrated production of low-value high-volume (i.e. ethanol from pretreated material) and high value low-volume products (i.e. succinate from pretreatment liquor and thin stillage after ethanol recovery) from rapeseed straw after dilute-acid pretreatment under high biomass loading.

\section{Materials and Methods}

\subsection{Feedstock}


The straw used in this study originated from rapeseed cultivated for energy purposes. The farm, which provided the material, is located in the Silesia province; south of Poland. Dry straw was chopped using a shredder (4-5 cm length) and ground to particles of about $3 \mathrm{~mm}$; using a cutting mill. The dry matter (DM) content was $95.2 \pm$ $0.2 \%$. The characteristics of the rape straw are presented in Table 1 .

2.2. Biomass pretreatment and enzymatic hydrolysis

Rapeseed straw $(10 \%, 15 \%, 20 \%$ and $25 \% \mathrm{w} / \mathrm{v})$ was mixed with $1 \%$ solution of $\mathrm{H}_{2} \mathrm{SO}_{4}$ and treated in a batch reactor at $180{ }^{\circ} \mathrm{C}$ for $10 \mathrm{~min}$. The amount of sulfuric acid used as catalyst was previously established during our previous studies (Lu et al., 2009). It is also in accordance with other reports (Jung et al., 2013, Talebnia et al., 2015). All pretreatment assays were repeated four times. After pretreatment, the slurry was filtrated by vacuum pump, obtaining two fractions, namely, solid and liquid (pretreatment liquor) fractions, respectively. Small amounts of solid fraction were dried at $105{ }^{\circ} \mathrm{C}$ and used for analysis of the chemical composition. The rest of the solid fraction was used for enzymatic hydrolysis, while the pretreatment liquor was used as feedstock for succinic acid production (section 2.4).

Solid fractions (rapeseed straw pretreated by diluted acid at $20 \% \mathrm{w} / \mathrm{v}$ loading) were used as feedstock for enzymatic hydrolysis. Enzymatic hydrolysis was also performed on untreated rapeseed straw (non-pretreated by dilute acid method) to compare with enzymatic assays of pretreated biomass (Table 3).

Enzymatic hydrolysis was conducted at a solid loading of 5\% (w/v) in a $50 \mathrm{mM}$ sodium citrate buffer, pH 5.4 at $50{ }^{\circ} \mathrm{C}$ for 48 h. Cellic ${ }^{\circledR}$ CTec2 (64.6 FPU/g) and Cellic ${ }^{\circledR}$ HTec2 (10.3 FPU/g) were used for enzymatic hydrolysis. Enzymatic cocktails dosages varied between $3 \%$ and $16 \%(\mathrm{w} / \mathrm{w})$ and and were expressed as percentage of substrate 
dry matter. Additionally, $10 \%$ and $20 \%$ of Cellic ${ }^{\circledR}$ CTec 2 of total $13 \%$ w/w dosage (considered as the optimal), was replaced with Cellic ${ }^{\circledR}$ HTec2 - reach in endoxylanases (Table 3). Cellulase activity was determined following NREL procedure and expressed as units of filter paper (FPU) per gram of enzyme solution (Adney and Baker, 2008).

\subsection{Ethanol production}

The culture of S. cerevisiae was first subcultured on Yeast Mold (YM) Agar. For ethanol production, residues after enzymatic hydrolysis (R4 - biomass hydrolyzed with $13 \%$ w/w of Cellic ${ }^{\circledR}$ CTec2 dosage and R6 - biomass hydrolyzed with total $13 \%$ w/w of Cellic ${ }^{\circledR}$ CTec2 and Cellic HTec2 dosage: Cellic ${ }^{\circledR}$ CTec2 to Cellic ${ }^{\circledR}$ HTec2 ratio of 90:10, Table 3) were used for ethanol production, so that were supplemented with $S$. cerevisiae and minerals as previously described (Kuglarz et al., 2014). Fermentation was performed at $30{ }^{\circ} \mathrm{C}$ for $48 \mathrm{~h}$ in $300 \mathrm{~mL}$ Pyrex flasks equipped with air locks. Samples of $1 \mathrm{~mL}$ were taken after 0,3, 6, 12, 24, 36 and 48 h. Samples were centrifuged at $10.000 \mathrm{~g}$ for $10 \mathrm{~min}$. and then the supernatants were filtered with $0.2 \mu \mathrm{m}$ pore size filters - before sugars and ethanol determination. After fermentation, ethanol was removed from the solution by membrane filtration (Osmonics unit) under transmembrane pressure of $2 \mathrm{MPa}$. The samples were filtered until about $80 \%$ of the initial volume and the filtrate was recorded as a permeate. In the present study, the main aim of membrane filtration was to separate the produced ethanol from fermentation broths, so that the retentate, (i.e the fraction rich in C5 sugars), was further used as feedstock for succinic acid production. Membrane fouling and economical aspects connected with operating costs were not included in this study.

\subsection{Succinic acid production}


Pretreatment liquors $\left(S_{\text {after pret. }}\right)$ and the residue after ethanol recovery $\left(S_{\text {after EtOH }}\right)$ were used as feedstock for succinic acid production. Additionally, $\mathrm{pH}$ of liquid fraction after pretreatment ( $\mathrm{S}_{\text {after pret. }}$ ) was adjusted to about 6.5, using $2 \mathrm{M} \mathrm{NaOH}$. Samples of neutralized liquid were centrifuged for $10 \mathrm{~min}$. and then the supernatants were filtered via $0.2 \mu \mathrm{m}$ pore size. Both feedstocks $\left(S_{\text {after pret. }}\right.$ and $\left.S_{\text {after EtOH }}\right)$ were autoclaved at 121 ${ }^{\circ} \mathrm{C}$ for $20 \mathrm{~min}$. Seed culture medium composition and way of preparation were previously described (Gunnarsson et al., 2015). Each substrate was fermented separately in batch mode, using three identical $2 \mathrm{~L}$ fermenters. All reactors were operated with an initial volume of $1.0 \mathrm{~L}$ at $37^{\circ} \mathrm{C}$ for $48 \mathrm{~h}$. The fermentation was conducted by mixing sterile substrates (pretreatment liquor: $S_{\text {after pret }}$ or residue after ethanol fermentation: $\left.\mathrm{S}_{\mathrm{after} E \mathrm{EtOH}}\right)$ with synthetic experimental medium at 100:0, 80:20 and 60:40 (v:v) ratios. Assay without synthetic medium (nutrients) was also conducted. In each case, about 5\% (v:v) of exponentially growing inoculum $\left(\mathrm{OD}_{660}=4.5\right)$ was added. Actinobacillus succinogenes 130Z (DSM 22257) was obtained from DSMZ (German Collection of Microorganisms and Cell Cultures). A. succinogenes, used in the current study, had a concentration of $0.622 \mathrm{~g}$ dry cell weight $(\mathrm{DCW}) \mathrm{L}^{-1}$. The start-up of the fermenters was previously described (Gunnarsson et al., 2015). $1 \mathrm{~g}$ of solid $\mathrm{MgCO}_{3}$ per $1 \mathrm{~g}$ of total sugar was supplied and acted as an indirect $\mathrm{CO}_{2}$ source and $\mathrm{pH}$ buffer of fermentation medium. Samples of $1 \mathrm{~mL}$ were taken (after 0, 3, 6, 12, 15, 18, 24, 36, $48 \mathrm{~h}$ ) and used for analysis of sugars (glucose, xylose), acids (succinic, acetic, formic, lactic) and optical density at $660 \mathrm{~nm}\left(\mathrm{OD}_{660}\right)$ measurements.

\subsection{Analytical methods}

Total solids (TS), volatile solids (VS), ash and protein content were determined according to standards methods (APHA, 2005). $\mathrm{pH}$ was measured using a standard $\mathrm{pH}$ 
meter. The content of cellulose, hemicellulose and lignin in raw material as well as solid residues after pretreatment were determined according to the National Renewable Energy Laboratory (NREL) analytical methods for biomass characterization (Sluiter et al., 2012). Concentrations of sugars (glucose, xylose, arabinose), ethanol, organic acids (acetic, formic, succinic, lactic) were measured by high performance liquid chromatography HPLC (Agilent 1260) equipped with a BioRad Aminex HPX-87 H at $63{ }^{\circ} \mathrm{C}$ and refractive index (RI) detector (RID 1362A) using $0.6 \mathrm{ml} / \mathrm{min}$ of $4 \mathrm{mM} \mathrm{H}_{2} \mathrm{SO}_{4}$ as an eluent. Inhibitors generated during pretreatment (furfural and 5-hydroxymethyl- 2furaldehyde (HMF)) were detected by HPLC fitted with ultraviolet (UV) detector. In case of succinic acid fermentation, cell growth $\left(\mathrm{OD}_{660}\right)$ was monitored by measuring the optical density at $660 \mathrm{~nm}$, using a spectrophotometer (Hach Lange DR 5000). Before OD analyses, insoluble $\mathrm{MgCO}_{3}$ was removed, by mixing the sample with $7 \%$ (w/v) $\mathrm{HCl}$ at the ratio of $1: 1$.

\subsection{Calculations}

\subsubsection{Pre-treatment}

The increase/decrease (\%) of analyzed biomass components after pretreatment was calculated in accordance with its initial content in untreated biomass and presented as the percentage. The amount of FIS (fraction insoluble solids after pretreatment) was calculated according to Kuglarz et al. (2016).

Inhibitor yields were based on the amount of furfural and HMF (5hydroxymethyl- 2-furaldehyde) released into pretreatment liquor during acid pretreatment and are calculated according to Eq. (1) (furfural yield) and Eq. (2) (HMF yield):

$$
Y_{\text {Furfural }}(\%)=\frac{\text { Furfural } \cdot\left(\frac{132}{96}\right)}{\text { Hemicellulose }_{\text {Initial }}} \cdot 100
$$




$$
Y_{H M F}(\%)=\frac{H M F \cdot\left(\frac{162}{126}\right)}{\text { Glucan Initial }_{\text {In }}} \cdot 100
$$

where:

Furfural - amount of furfural released during pretreatment into pretreatment liquor, $\mathrm{g}$ HMF - amount of HMF released during pretreatment into pretreatment liquor, $\mathrm{g}$ Glucan $_{\text {Initial }}$ - glucan content in untreated biomass used for pretreatment, $\mathrm{g}$ Hemicellulose $_{\text {Initial }}$ - xylan and arabinan content in the untreated biomass used for pretreatment, g

(132/96) - conversion factor including MW (molecular weight) of xylose unit and MW of furfural

(162/126) - conversion factor, including MW of glucose and MW of HMF (5hydroxymethyl- 2-furaldehyde)

\subsubsection{Sugar yields}

Total yields of biomass hydrolysis (pretreatment and enzymatic hydrolysis) were calculated as follows: (Eq. ((3-5)):

$$
\begin{aligned}
& \operatorname{Total}_{\mathrm{Glu} .}(\%)=\frac{\text { Glucose }_{\text {Pret. }}+\text { Glucose }_{\text {Enz. }}}{\text { Glucan }_{\text {Initial }} \cdot\left(\frac{180}{162}\right)} \cdot 100(3) \\
& \operatorname{Total}_{\text {Xyl. }}(\%)=\frac{\text { Xylose }_{\text {Pret. }}+\text { Xylose }_{\text {Enz. }}}{\text { Xylan }_{\text {Initial }} \cdot\left(\frac{150}{132}\right)} \cdot 100(4) \\
& \operatorname{Total}_{\text {Sugar }}(\%)=\frac{\text { Glucose }_{\text {Pret. }+ \text { Enz. }}+(\text { Xylose }+ \text { Arabinose })_{\text {Pret.tEnz. }}}{\left[\text { Glucan }_{\text {Initial }} \cdot\left(\frac{180}{162}\right)+\text { Xylan }_{\text {Initial }} \cdot\left(\frac{150}{132}\right)+\text { Arabinan }_{\text {Initial }} \cdot\left(\frac{150}{132}\right)\right]} \cdot 100
\end{aligned}
$$

where:

Glucose $_{\text {Pret.., }}$ Xylose $\mathrm{P}_{\text {Pret., }}$ - the amount of glucose and xylose released to liquor during pretreatment; g.

Glucose $_{\text {Enz., }}$ Xylose $e_{\text {Enz., }}-$ the amount of glucose and xylose released during enzymatic hydrolysis, respectively, g. 
(180/162) - stoichiometric conversion factor of glucan to glucose

(150/132) - stoichiometric conversion factor of xylan to xylose

\subsubsection{Ethanol fermentation}

Effectiveness of ethanol fermentation was based on the assumption that all glucose found in the feedstock could be converted by $S$. cerevisiae into ethanol, with a yield of $0.51 \mathrm{~g} \mathrm{EtOH} / \mathrm{g}$ of glucose. Ethanol yield ( $\left.\mathrm{Y}_{\mathrm{EtOH}}\right)$ was calculated according to the following equation (Eq. (6)):

$$
Y_{\text {EtOH }}(\%)=\frac{Y_{\text {EtOH-prac. }}}{0.51 \frac{g-E t O H}{g-\text { glucose }}} \cdot 100(6)
$$

where:

$\mathrm{Y}_{\mathrm{EtOH}-\mathrm{prac} .}-$ practical ethanol yield, representing the highest ethanol amount obtained in fermentation process per $1 \mathrm{~g}$ of glucose consumed, g-EtOH/g-glucose.

Ethanol production was also expressed as the amount of ethanol produced per unit of biomass treated (kg-ethanol/Mg of biomassrapeseed straw).

\subsubsection{Succinic acid fermentation}

Succinic acid yield $\left(\mathrm{Y}_{\mathrm{SA}}\right)$ was calculated as the amount of succinic acid $(\mathrm{g})$ obtained per $1 \mathrm{~g}$ of sugars (glucose + xylose) consumed (Eq. (7)).

$$
Y_{S A}(\%)=\frac{\text { SA }_{\text {Prod. }}}{\text { Sugar }_{\text {Consumed }}} \cdot 100(7)
$$

where:

$\mathrm{SA}_{\text {Prod. }}$ - concentration of succinic acid produced $\left(\mathrm{g} \mathrm{L}^{-1}\right)$;

Sugar $_{\text {Consumed }}$ - amount of glucose and xylose consumed during succinic acid fermentation $\left(\mathrm{g} \mathrm{L}^{-1}\right)$.

Succinic production was also expressed as the amount of acid produced per unit of biomass treated (kg-succinic acid/Mg of biomass). 


\subsection{Statistical analysis}

All results are presented as average values with standard deviations $( \pm)$. The characteristics of untreated and pretreated hemp (content of cellulose, hemicellulose and lignin) as well as yields achieved during enzymatic hydrolysis and total hydrolysis yields (pretreatment + enzymatic hydrolysis) were compared statistically. One-way ANOVA test followed by Tukey's HSD tests were used for multiple comparisons between samples, with the level of significant set at 0.05 . The same letters represent data equivalent statistically $(\mathrm{p}>0.05)$.

\section{Results and discussion}

\subsection{Feedstock composition}

The main components of the rapeseed straw used as a feedstock in this study were cellulose (35.5\%), hemicellulose (20.9\%) and lignin (21.7\%) (Table 1). Xylose was the main monomeric sugar (18.9\%) present in the hemicellulose fraction and the rest constituted arabinose $(2.1 \%)$. Ash and protein amounted to $5.1 \%$ and $2.5 \%$, respectively (data not shown). The other components (14\% of dry matter), which were not identified can include non-structural components, such as waxes, resins etc. The composition of rapeseed straw was in accordance with previous reports (Talebnia et al., 2015, Lu et al., 2009). Overall, total carbohydrates content in rapeseed straw currently analysed (56\% of dry matter) makes this substrate a promising feedstock for biofuels and/or biochemical production.

\subsection{Biomass pretreatment}

\subsubsection{Content of carbohydrates and lignin in pretreated biomass}

Glucan content, the main carbohydrate component recovered after biomass pretreatment at loading between 10-20\%, increased by 48-53\% (data equivalent statistical- 
ly, $\mathrm{p}>0.05)$ compared to its initial content. Higher biomass loading $(25 \%)$ led to a significant decrease of residual glucan content in the pretreated material. Similar correlation was observed in case of other types of biomasses. For example, sugarcane pretreated at $10-25 \%$ loading gave almost the same sugar yield as in the current study. Whilst, a decrease in sugar yield was observed above this level (Sindhu et al., 2011). Regardless of the biomass loading, between $96-99 \%$ of glucan was retained in solid fractions (data equivalent statistically, $\mathrm{p}>0.05$ ) (Table 1). There were only insignificant amounts of glucose detected in pretreatment liquors $\left(>1 \mathrm{~g} \mathrm{~L}^{-1}\right)$ (Table 2), which is an advantage of the pretreatment conditions used.

Table 1.

Xylose was the main hemicellulose monomer released in the pretreatment liquor. Between $44-50 \%$ of xylan was solubilized at biomass loading between 10-20\% (data equivalent statistically, $\mathrm{p}>0.05)$. At these conditions (10-20\% biomass loading), between $56-63 \%$ of arabinan was released pretreatment liquor (Table 2). However, arabinose concentration in pretreatment liquor was low (2.0-2.5 $\left.\mathrm{g} \mathrm{L}^{-1}\right)$ (Table 2), due to low content of arabinan in the biomass before pretreatment (2.1\% dry matter). There was no arabinan detected in solid material after pretreatment (data not shown). Hemicellulose solubilization allowed to decrease its content in the pretreated material (solid fractions) by $62-71 \%$ compared to its initial content. Whilst, pretreatment at the highest biomass loading (i.e. 25\%) caused a significantly lower solubilization of hemicellulosic monomers, i.e. only about $28 \%$ and $49 \%$ of initial (before pretreatment) xylan and arabinan were solubilized, respectively (Table 2). This can be connected with lower accessibility of the pretreatment agent $\left(\mathrm{H}_{2} \mathrm{SO}_{4}\right)$ and reduced steam diffusion at higher solid loadings. 
High biomass loading during pretreatment is also associated with difficulties in mixing. This is in agreement with previous studies (Sindhu et al., 2011, Mathew et al. 2011).

After carbohydrates, lignin constituted the second major component of biomass after pretreatment. Lignin content increased in the solid fraction by $52-54 \%$ (pretreatment at $10-20 \%$ biomass loading (data equivalent statistically, $\mathrm{p}>0.05$ ) and $40 \%$ (pretreatment at $25 \%$ biomass loading) compared to its content in untreated biomass. The reason of the increase of lignin in the solid fraction was due to decrease of the polymeric carbohydrates content. Thereby the lignin content relative to organics in the solid fraction, was higher. Regarding the residual lignin, between $97-102 \%$ of initial lignin was recovered in solid fractions after pretreatment (Table 1); with no soluble lignin detected in pretreatment liquor. This is in agreement with previous studies, as steam pretreatment with sulfuric acid is not effective in biomass delignification (Gunnarsson et al., 2015, Kuglarz et al., 2016). Values slightly exceeding 100\% might be connected with re-polymerization of dissolved lignin during polysaccharide degradation.

Table 2.

\subsubsection{Formation of degradation products}

In the present study, acetic acid was observed as the main degradation product, which was equivalent to $4-8 \%$ of xylan present in the biomass before pretreatment (Table 2). As the biomass concentration during pretreatment increased from 10-15 to $20 \%$, the concentration of acetic acid increased by $46-98 \%$ (data statistically different, $\mathrm{p}$ $<0.05$, Table 2). Its occurrence is mostly associated with hydrolysis of acetylated hemicellulose and is commonly observed in case of biomass pretreated by stream methods or acid-based pretreatments. Released acetic acid has an ability to further decrease the $\mathrm{pH}$ value and can promote acid-catalyzed hydrolysis of biomass (Oh et al., 
2015). Significantly lower content of acetic acid, recorded for the biomass loading of $25 \%$, was strictly connected with the lower biomass conversion, i.e. sugar release (Table 1 and 2). As regards to other glucan- and xylan-based by-products, low concentrations of furfural $\left(\leq 0.5 \mathrm{~g} \mathrm{~L}^{-1}\right)$ and $\mathrm{HMF}\left(\leq 0.2 \mathrm{~g} \mathrm{~L}^{-1}\right)$ were recorded, which were equivalent to about $0.8-1.1 \%$ (hemicellulose) and $0.2-0.3 \%$ (cellulose), respectively. There was no significant influence of biomass loading (during pretreatment) on the amount of furfural and $\mathrm{HMF}$ released (data equivalent statistically, $\mathrm{p}>0.05$ ) (Table 2).

Results obtained in this study clearly showed that the conditions of acid-based pretreatment of rapeseed straw did not generate significant amounts of degradation products, which is a benefit of this method. Considering effectiveness of the pretreatment, rapeseed straw pre-treated at loading of 10-20\% allowed to reach the highest content of glucan in biomass dry matter, i.e. 52-54\% (data equivalent statistically, $\mathrm{p}>0.05$, Table 1). However, the process based on $20 \%$ biomass loading ensured the highest release of $\mathrm{C} 5$ sugars from lignocellulosic complex into pretreatment liquor, which constitutes a valuable feedstock for the production of added value compounds (Tâble 2).

\subsection{Enzymatic hydrolysis}

The glucose yield of untreated feedstock amounted to $32 \%$ after $48 \mathrm{~h}$ of enzymatic hydrolysis (Table 3). This proves that rapeseed straw without pretreatment is difficult to hydrolyze. In case of pretreated biomass, overall glucose concentrations (after diluteacid pretreatment + enzymatic hydrolysis) were significantly higher in comparison to the one obtained when solely enzymatic hydrolysis of rapeseed straw was conducted; which proves the effectiveness of acidic pretreatment applied before enzymatic hydrolysis (Table 3). The course of all enzymatic assays is presented in Appendix A (supple- 
mentary material). Depending on the enzyme loading of newer generation enzyme preparations (Cellic ${ }^{\circledR}$ CTec2), glucose and xylose yields after $48 \mathrm{~h}$ of hydrolysis, ranged from $44 \%$ to $80 \%$ and from $50 \%$ to $99.5 \%$ respectively (Table 3 ). The plot of initial rates of glucose and xylose release (based on the experimental results obtained during early stages of enzymatic hydrolysis, for zero order kinetics of product formation, data not shown) versus concentration of Cellic ${ }^{\circledR} \mathrm{CTec} 2$ are presented in Fig. 1. For experiments carried out with enzymes loadings of up to about $10 \%$, linear relationships were observed. This means that the amount of catalysts in the glucan and xylan hydrolysis is the limiting factor, i.e. reaction rates are dependent upon the concetration of enzymes. For higher dosage of Cellic ${ }^{\circledR} \mathrm{CTec} 2$, rates of both glucose as well as xylose release were not directly proportional to the amount of enzyme present in reaction mixture (relation between the hydrolysis rates versus enzyme concentration response becomes nonlinear), most probably due to the saturation of substrate by enzymes. Increase of Cellic ${ }^{\circledR} \mathrm{CTec} 2$ loading from $10 \%(\mathrm{w} / \mathrm{w})$ to $13 \%(\mathrm{w} / \mathrm{w})$ resulted in increase of total sugar yield from 66 to $80 \%$ (Table 3 ). These enzyme dosages correlated with cellulase activity (12 FPU/gglucan) and (16 FPU/g-glucan), respectively. It is worth mentioning that enzymatic hydrolysis results obtained with the use of Cellic ${ }^{\circledR} \mathrm{CTec} 2$ at optimized conditions (13\% w/w) were significantly higher (glucose yield: 79-80\%) than the ones obtained by means of Celluclast ${ }^{\circledR} 1.5$ L/Novozyme 188 cocktail (glucose yield: 56-64\%, 10-13\% w/w enzyme dosage) (supplementary material). Further increase of Cellic ${ }^{\circledR}$ CTec2 (Table 3) and Celluclast ${ }^{\circledR}$ dosage (data not shown) did not impact the effectiveness of enzymatic hydrolysis.

Table 3. 
In order to increase the effectiveness of the enzymatic hydrolysis, especially if the hydrolysed feedstock contains considerable amount of xylan, it is recommended to supplement Cellic ${ }^{\circledR}$ CTec2 with reach in endoxylanases - Cellic ${ }^{\circledR}$ HTec2. In our case, Cellic ${ }^{\circledR}$ CTec2 supplementation with Cellic ${ }^{\circledR}$ HTec 2 had a positive influence on the rate of glucan conversion (Appendix A, supplementary material). This is in agreement with previous studies, e.g. Pengilly et al. (2015). Regardless of the enzyme replacement, the final concentration of glucose was almost the same (data statistically equivalent, $p$ > 0.05, Table 3). However, application of Cellic HTec2 reduced the hydrolysis time by 44-46\% required to achieve the maximum glucan conversion (Appendix A, supplementary material). Whilst, there was no significant difference as regards glucose yields between samples supplemented by $10 \%$ and $20 \%$ of Cellic ${ }^{\circledR}$ HTec2 (Table 3). Both replacements $(10 \%$ and $20 \%)$ of Cellic ${ }^{\circledR}$ CTec2 by Cellic ${ }^{\circledR}$ HTec2 gave almost the same xylose concentration after $48 \mathrm{~h}$ of hydrolysis (data equivalent statistically, Table 3). However, these values were significantly higher than xylose yields obtained in the case of using only Cellic ${ }^{\circledR}$ CTec2 as catalyst (data statistically different $\mathrm{p}<0.05$, Table 3). Taking into account the effect of enzyme loading on initial reaction rate (Fig. 1) and final glucose and xylose yields (Table 3), application of Cellic ${ }^{\circledR} \mathrm{CTec} 2$ preparation at a concentration of $13 \%(\mathrm{w} / \mathrm{w})$ seems to be the most appropriate for hydrolysis of rapeseed straw pretreated with $1 \% \mathrm{H}_{2} \mathrm{SO}_{4}$ under high biomass loading (20\% w/v). Additionally, replacement of $10 \%$ Cellic $^{\circledR}$ CTec2 by Cellic ${ }^{\circledR}$ HTec2 resulted in significant improvement of xylan hydrolysis. Compared to other biomass types, the results obtained in the present study show the beneficial effect of using pretreated rapeseed straw under high biomass loading (20\% w/v) as feedstock for enzymatic hydrolysis with Cellic ${ }^{\circledR}$ CTec 2 cocktails. For example, $60-80 \%$ of glucan was hydrolysed in case of corn 
stover or cobs pretreated by dilute acid method, but pretreatment processes were conducted under significantly lower biomass loadings ( $\leq 10 \%$ ) (Van Eylen et al., 2011, Tai and Keshwani, 2014)

\subsection{Ethanol production}

Ethanol production started immediately without any lag phase. After $24 \mathrm{~h}$ of the fermentation, 97-98\% of glucose was consumed and 0.45-0.46 g EtOH/g-glucose was produced. These values correspond to an ethanol yield of $88-90 \%$ (based on results presented in Fig. 2, according to Eq. (6)). Despite different enzyme cocktails used no significant differences in effectiveness of ethanol fermentation between batches was observed, which was expected due to the fact that in both cases similar amounts of glucose were released during enzymatic hydrolysis. The ethanol yield of "pure glucose" was also analyzed and the values amounted to $0.49 \mathrm{~g}-\mathrm{EtOH} / \mathrm{g}$-glucose (data not shown). Ethanol production obtained in this study (13.0-13.5 g/100 g of biomass) was slightly lower than previously reported for rapeseed straw (14-15 g/100 g of biomass) (Luo et al., 2011). However, the straw before enzymatic hydrolysis and fermentation was pretreated by complete different method $\left(3 \% \mathrm{v} / \mathrm{v} \mathrm{H}_{2} \mathrm{O}_{2}\right)$ and significantly lower biomass loading (i.e. 10\%) was used compared to our current studies. Fig. 2.

In case of the sample hydrolyzed without endoxylanases supplementation (R4 assay, Table 3), xylose concentration increased by $15 \%$ during fermentation (Fig. 2). Xylose finally reached the value recorded for the sample hydrolysed by the mixture of Cellic ${ }^{\circledR}$ CTec2 and Cellic ${ }^{\circledR}$ HTec2 (R6 assay, Table3). This increase was accounted for the presence of enzymes added during enzymatic hydrolysis. The xylose was not consumed by native $S$. cerevisiae (non-engineered) (Talebnia et al., 2010; Kuglarz et al., 
2014). In the present study, membrane filtration was applied to separate produced ethanol from fermentation broths. In both filtration cases (hydrolysed by Cellic CTec2 with and without endoxylanases supplementation), ethanol (>99\%) diffused by membranes (Fig. 2), which was expected due to the higher ethanol diffusivity $\left(12 \cdot 10^{-6}\right.$ $\left.\mathrm{cm}^{2} \mathrm{~s}^{-1}\right)$ through the membrane than xylose $\left(7.69 \cdot 10^{-6} \mathrm{~cm}^{2} \mathrm{~s}^{-1}\right)$. Moreover, ethanol has a very low molecular weight $\left(46.07 \mathrm{~g} \mathrm{~mol}^{-1}\right)$ compared to the cut off of the membrane used (100 Da) and thus the ethanol molecule might have sieved through the membrane contributing to separation of ethanol/xylose mixtures (Xiong et al., 2015). In this case, xylose was above 6 times more concentrated compared to its content in the residue after ethanol production (Fig. 2, Table 4). These are very promising results, taking into account biological conversion of xylose into succinic acid in the next step of the experiment. Taking into account the fact that post-digestion wastes contain minor amounts of inorganic salts added for microbial growth promotion during fermentation as well as various organic compounds (e.g. amino acids, peptides etc.) coming from yeast extract used as nitrogen source for fermentation (Cho et al., 2012), such liquors are considered as difficult to treat. However, one of the key steps of the present study was to concentrate xylose, - which can be effectively used in further experiments for biochemical production. Membrane fouling as well as economical aspects connected with operating costs were not included in this study.

\subsection{Succinic acid production}

Only a minor part of the sugards remained as residues after succinic acid production and between $86-91 \%$ of sugars were utilized during the process (Table 4). Glucose and xylose (the main sugar in analysed feedstock) were simultaneously consumed during succinic acid fermentation. There was no glucose detected after the process. Regard- 
less of the amount of medium added, residual xylose (2-3 $\mathrm{g} \mathrm{L}^{-1}$, Table 4) was recorded. Insignificant residual C5 sugars are commonly reported in the solution after succinic fermentation as the Actinobacillus succinogenes prefers glucose as substrate rather than C5 sugars (e.g. xylose) (Salvachúa et al., 2016). In case of $S_{\text {after pret, more than } 80 \% \text { of }}$ xylose was consumed as long as the fermentation mixture contained at least $20 \%$ of synthetic medium (nutrients + nitrogen). Fermentation of $S_{\text {after pret }}$ (without nutrient addition) resulted in a very low sugar utilization (38\%) and 4-10 times higher residual xylose levels compared to processes with $20-40 \%$ content of medium (Table 4). Fermentation of $S_{\text {after EtOH }}$ did not require nutrients supply, which can be explained by the fact that this substrate, is a complex feedstock containing nutrients (derived from nitrogen and nutrients added in ethanol fermentation step).

Succinic yields of 68-70\% and 60-61\% were achieved from $S_{\text {after EtOH }}$ and $S_{\text {after pret. }}$ (with at least $20 \%$ addition of medium), respectively. These values are within the upper range of succinic yields reported for xylose-based feedstock (Pateraki et al., 2016, Gunnarsson et al., 2015). Taking into account the fact that inhibitors (HMF, furfural) present in the pretreatment liquor were below inhibition levels (Xi et al., 2013), slightly lower yields obtained from $S_{\text {after pret. }}$ compared to residue after ethanol fermentation ( $\left.\mathrm{S}_{\text {after EtOH }}\right)$ might have been caused by the presence of degradation products other than the ones analysed in the present study. No furfural and HMF were observed after succinic fermentation (data not shown). This is consistent with previous findings stating that A. succinogenes has the ability to reduce furfural and HMF into corresponding alcohols (Salvachua et al., 2016). There was no significant difference in final succinic acid titer and yield recorded for samples originated from different conditions of enzymatic hydrolysis applied before ethanol fermentation (R4 and R6, Table 4, data equiva- 
lent statistically $\mathrm{p}>0.05)$. This was accounted for the fact that both residues contained a similar amount of xylose (the main sugar). In the first $12-15 \mathrm{~h}$, cells grew rapidly and cell density shown as DCW reached the highest values. After 3-6 h a short steady stage, the DCW values started to decrease (Appendix A, supplementary material). The drop in DCW value was attributed to cell flocculation, which depends on feedstock source, nutritional and physicochemical factors etc. This is in agreement with previous studies, e.g. Chen et al. (2016). The highest succinic acid productivity, $0.46-0.5 \mathrm{~g} \mathrm{~L}^{-1} \mathrm{~h}^{-1}$ (between 0 and $24 \mathrm{~h}$; cell growth and steady phase), was observed when fermenting $\mathrm{S}_{\text {after }}$ EtOH (without medium addition or at 20:80 mixing ratio). $S_{\text {after pret. feedstock exhibited }}$ the highest succinic productivity when mixed with $20 \%$ of medium (nutrients + nitrogen). In all cases, the succinate productivity decreased $\left(<0.2 \mathrm{~g} \mathrm{~L}^{-1} \mathrm{~h}^{-1}\right)$ after $24 \mathrm{~h}$ of the process (decrease in cell density, Appendix A). This is in agreement with previous results stating that succinate productivity decreases after biofilm formation, however, succinate production does not cease (Salvachúa et al., 2016).

In the present study, acetic- and formic acid were produced as the main fermentation by-products. In the initial growth phase, concentrations of acetic and formic acid were proportional to the succinic acid concentration. After 18-24 h (decrease in cell density), the production of acetic and formic acids ceased. This can be due to the low cell-biomass generation during stationary phase and thereby lower energy requirements - the pathways connected with acetic and formic acid are suppressed. As a consequence, the carbon flux shifts towards succinic acid production (Pateraki et al., 2016). Concentrations of acetic and formic acid present in the feedstock (pretreatment liquor) as well as in succinic broths were several times lower than the critical values reported for $A$. succinogenes (Lin et al., 2008). However, higher total accumulation of by-products 
(acetic and formic acid) obtained for fermentation of pretreatment liquor $\left(\mathrm{S}_{\text {after pret. }}\right)$ can be responsible for a slightly lower succinic yields compared to residues after ethanol fermentation $\left(\mathrm{S}_{\mathrm{after} \mathrm{EtOH}}\right)$. This is in accordance with previous research stating that it is rather the total acids concentration that is responsible for process inhibition than individual acids (Lin et al., 2008).

Table 4.

\subsection{Biorefinery concept}

During acid-based pretreatment of rapeseed straw in conditions selected as optimal $\left(1 \% \mathrm{H}_{2} \mathrm{SO}_{4}, 20 \%\right.$ biomass loading, Table 1 and 2), $67 \%$ of the DM was transferred to solid fraction (FIS), whilst almost $20 \%$ was transferred to pretreatment liquor (Fig. 3). In both types of enzyme cocktails tested (Cellic ${ }^{\circledR}$ CTec 2 and Cellic ${ }^{\circledR}$ CTec 2 with $10 \%$ supplementation of endoxylanases, Cellic ${ }^{\circledR}$ HTec2), similar glucan conversions were achieved. However, application of enzymatic mixture supplemented with endoxylanases allowed to generate about $10 \%$ more xylose compared to the process conducted by using only Cellic ${ }^{\circledR}$ CTec2 (Fig. 3, Table 4). Using ordinary baker's yeast, S. cerevisiae, significantly similar amounts of ethanol were produced (122-125 kg EtOH/Mg of dry straw) after both enzymatic cocktails (Fig. 3). Significantly higher amounts of succinic acid was produced from fermentation of $S_{\text {after pret. }}(48 \mathrm{~kg} / \mathrm{Mg}$ of dry straw) compared to fermentation of xylose-rich residue $\left(S_{\text {after EtOH }}\right)(35-37 \mathrm{~kg} / \mathrm{Mg}$ of dry straw) (Fig. 3). However, succinic acid content in carboxylic acid mixture after fermentation of pretreatment liquor was significantly lower, i.e. 55\% compared to the fermentation of the residue after ethanol fermentation, i.e. $72-73 \%$ (calculated based on results presented in Fig. 3). This was explained by the fact that acetic acid was released into pretreatment liquors, mostly due to hydrolysis of acetylated hemicellulose (Table 2). 
Decreased ratio of succinic acid to by-products increases the costs of succinic acid recovery from the broth. It is estimated that $50-70 \%$ of the total costs of succinic acid production is allocated to the purification step, while only $20-25 \%$ of the costs are connected with fermentation process. The purification costs are mostly attributed to refining processes in order to obtain the final product with high purity (Li et al., 2016). The succinic yield and sugar utilization presented in the current study can be further improved by conducting the fermentation in more controlled bioreactors; ensuring stable mixing and $\mathrm{pH}$ during the whole process (Chen at al., 2011). Additionally, the economy of a biorefinery approach based on straw after acid-based pretreatment can be improved by effective utilization of lignin fraction. In this study, the solid fraction after pretreatment contained 32\% DM of lignin (Table 1), which is equivalent to $215 \mathrm{~kg}$ (from $1 \mathrm{Mg}$ of dry straw) (Fig. 3). Separated lignin can be used for heat or heat and power generation and integrated with lignocellulosic biorefinery for energy-intensive processes, such as: biomass pretreatment, ethanol distillation, purification of succinic acid from fermentation broths. It should be taken into account that the present study is a simplified analysis, which is focused on products (lignocellulosic ethanol and succinic acid). The results obtained can be used as an important input for extended environmental and economic analyses to document the rapeseed straw utilization in a biorefinery approach.

Fig. 3.

\section{Conclusions}

The results obtained clearly showed that rapeseed straw can be used for cellulosic bioethanol and succinic acid production in a biorefinery approach. Succinic acid was effectively produced from liquor generated during biomass acid-based pretreatment and 
xylose-based residues after ethanol fermentation. Optimal conditions of straw processing (20\% biomass loading, hydrolysis with Cellic ${ }^{\circledR} \mathrm{CTec} 2$ ) identified in this study can pave the way towards sustainable biomass utilization and improvement of lignocellulosic bioethanol economy due to the co-production of high value succinic acid as one of the most promising building-block chemicals.

Supplementary material

E-supplementary data of this work can be found in online version of the paper. Acknowledgements

This work was supported by the University of Bielsko-Biala within internal funds for development of young scientists, EU project POKL04.01.02-00-196/09-00 and Energinet (ForskEL-1219). The authors claim no conflict of interest concerning any part of the work presented.

\section{References}

1. Adney, B., Baker, J., 2008. Measurement of Cellulase Activities. Laboratory Analytical Procedure (LAP). Technical Report NREL/TP-510-42628, USA.

2. APHA, 2005. Standard Methods for the Examination of Water and Wastewater, $21^{\text {st }}$ ed. American Public Health Association Fed., Washington DC, USA.

3. Boldrin, A., Balzan, A., Astrup, T.F., 2013. Energy and environmental analysis of a rapeseed biorefinery conversion process. Biomass Convers. Biorefin. 3, 127-141.

4. Cannella, D., Jørgensen, H., 2014. Do new cellulolytic enzyme preparations affect the industrial strategies for high solids lignocellulosic ethanol production?. Biotechnol. Bioeng. 111, 59-68. 
5. Chen, K.Q., Li, J.A., Ma, J.F., Jiang, M., Wei, P., Liu, Z.M., Ying, H.J., 2011. Succinic acid production by Actinobacillus succinogenes using hydrolysates of spent yeast cells and corn fiber. Bioresour. Technol. 102, 1704-1708.

6. Chen, P.C., Tao, S.T, Zheng, P., 2016. Efficient and repeated production of succinic acid by turning sugarcane bagasse into sugar and support. Bioresour. Technol. 211, 406-413.

7. Cho, Y.H., Lee, H.D., Park, H.B., 2012. Integrated membrane processes for separation and purification of organic acid from a biomass fermentation process, Ind. Eng. Chem. Res. 51, 10207-10219.

8. Gunnarsson, I.B., Kuglarz, M., Karakashev, D., Angelidaki, I., 2015. Thermochemical pretreatments for enhancing succinic acid production from industrial hemp (Cannabis sativa L.). Bioresour. Technol. 182, 58-66.

9. Haven, M.O., Jørgensen, H., 2013. Adsorption of $\beta$-glucosidases in two commercial preparations onto pretreated biomass and lignin. Biotechnol. Biofuels 6, 165 .

10. Jeong, T.S., Um, B.H., Kim, J.S., Oh, K.K., 2010. Optimizing dilute-acid pretreatment of rapeseed straw for extraction of hemicellulose. Appl. Biochem. Biotechnol. 161, 22-33.

11. Jung, Y.H., Kim, I.J., Kim, H.K., Kim, K.H., 2013. Dilute acid pretreatment of lignocellulose for whole slurry ethanol fermentation. Bioresour. Technol. 132, 109114.

12. Kricka, W., Fitzpatrick, J., Bond, U., 2015. Challenges for the production of bioethanol from biomass using recombinant yeasts. Adv. Appl. Microbiol. 92, 89-125. 
13. Kuglarz, M., Alvarado-Morales, M., Karakashev, D., Angelidaki, I., 2016. Integrated production of cellulosic bioethanol and succinic acid from industrial hemp in a biorefinery concept. Bioresour. Technol. 200, 639-647.

14. Kuglarz, M., Gunnarsson, I.B., Svensson, S.E., Prade, T., Johansson, E., Angelidaki, I., 2014. Ethanol production from industrial hemp: Effect of combined dilute acid/steam pretreatment and economic aspects. Bioresour. Technol. 163, 236-243.

15. Li, Q.Z., Jiang X.L., Feng X.J., Wang J.M., Sun C., Zhang H.B., Xian M., Liu H.Z., 2016. Recovery processes of organic acids from fermentation broths in the biomassbased industry. J. Microbiol. Biotechnol. 26, 1-8.

16. Lin, S.K.C., Du, C.Y., Koutinas, A., Wang, R.H., Webb, C., 2008. Substrate and product inhibition kinetics in succinic acid production by Actinobacillus succinogenes. Biochem. Eng. J. 41, 128-135.

17. Lu, X.B., Zhang, Y.M., Angelidaki, I., 2009. Optimization of H2SO4-catalyzed hydrothermal pretreatment of rapeseed straw for bioconversion to ethanol: Focusing on pretreatment at high solids content. Bioresour. Technol. 100, 3048-3053.

18. Luo, G., Talebnia, F., Karakashev, D., Xie, L., Zhou, Q., Angelidaki, I., 2011. Enhanced bioenergy recovery from rapeseed plant in a biorefinery concept. Bioresour. Technol. 102, 1433-1439.

19. Luterbacher, J.S., Tester, J.W., Walker, L.P., 2012. Two-temperature stage biphasic $\mathrm{CO} 2-\mathrm{H} 2 \mathrm{O}$ pretreatment of lignocellulosic biomass at high solid loadings. Biotechnol. Bioeng. 109, 1499-1507.

20. Mathew, A.K., Chaney, K., Crook, M., Humphries, A.C., 2011. Dilute acid pretreatment of oilseed rape straw for bioethanol production. Renew. Energy 36, 24242432. 
21. Oh, Y.H., Eom, I.Y., Joo, J.C., Yu, J.H., Song, B.K., Lee, S.H., Hong, S.H., Park, S.J., 2015. Recent advances in development of biomass pretreatment technologies used in biorefinery for the production of bio-based fuels, chemicals and polymers. Korean J. Chem. Eng. 32, 1945-1959.

22. Pateraki, C., Patsalou, M., Vlysidis, A., Kopsahelis, N., Webb, C., Koutinas, A.A., Koutinas, M., 2016. Actinobacillus succinogenes: Advances on succinic acid production and prospects for development of integrated biorefineries. Biochem. Eng. J. 112, 285-303.

23. Pengilly, C., Garcia-Aparicio, M.P., Diedericks, D., Brienzo, M., Gorgens, J.F., 2015. Enzymatic hydrolysis of steam-pretreated sweet sorghum bagasse by combinations of cellulase and endo-xylanase. Fuel 154, 352-360.

24. Salvachua, D., Mohagheghi, A., Smith, H., Bradfield, M.F.A., Nicol, W., Black, B.A., Biddy, M.J., Dowe, N., Beckham, G.T., 2016. Succinic acid production on xylose-enriched biorefinery streams by Actinobacillus succinogenes in batch fermentation. Biotechnol. Biofuels 9, 28.

25. Sindhu, R., Kuttiraja, M., Binod, P., Janu, K.U., Sukumaran, R.K., Pandey, A., 2011. Dilute acid pretreatment and enzymatic saccharification of sugarcane tops for bioethanol production. Bioresour. Technol. 102, 10915-10921.

26. Sluiter, A., Hames, B., Ruiz, R., Scarlata C., Sluiter, J., Templeton, D., Crocker, D. Determination of Structural Carbohydrates and Lignin in Biomass. Laboratory Analytical Procedure (LAP) Issue Date: April 2008 Revision Date: August 2012 (Version 08-03-2012). 
27. Tai, C., Keshwani, D., 2014. Impact of pretreatment with dilute sulfuric acid under moderate temperature on hydrolysis of corn stover with two enzyme systems. Appl. Biochem. Biotechnol. 172, 2628-2639.

28. Talebnia, F., Karakashev, D., Angelidakki, I., 2010. Production of bioethanol from wheat straw: An overview on pretreatment, hydrolysis and fermentation. Bioresour. Technol. 101, 4744-4753.

29. Talebnia, F., Mighani, M., Rahimnejad, M., Angelidaki, I., 2015. Ethanol production from steam exploded rapeseed straw and the process simulation using artificial neural networks. Biotechnol. Bioprocess. Eng. 20, 139-147.

30. Van Eylen, D., van Dongen, F., Kabel, M., de Bont, J., 2011. Corn fiber, cobs and stover: Enzyme-aided saccharification and co-fermentation after dilute acid pretreatment. Bioresour. Technol. 102, 5995-6004.

31. Xi, Y.L., Dai, W.Y., Xu, R., Zhang, J.H., Chen, K.Q., Jiang, M., Wei, P., Ouyang, P.K., 2013. Ultrasonic pretreatment and acid hydrolysis of sugarcane bagasse for succinic acid production using Actinobacillus succinogenes. Bioprocess Biosyst. Eng. 36, 1779-1785.

32. Xiong, B.Y., Richard, T.L., Kumar, M., 2015. Integrated acidogenic digestion and carboxylic acid separation by nanofiltration membranes for the lignocellulosic carboxylate plantorm. J. Membr. Sci. 489, 275-283. 


\section{Figure captions}

Fig. 1. Relationship between initial hydrolysis rates and Cellic ${ }^{\circ}$ CTec2 dosage used (filled circle - glucose, unfilled circle - xylose)

Fig. 2. Ethanol fermentation course (A-B) and concentration of xylose and ethanol in permeate $(\mathrm{C}-\mathrm{D})$ during broth filtration $((\mathrm{A}, \mathrm{C})$ - straw hydrolysed with $13 \% \mathrm{w} / \mathrm{w}$ Cellic ${ }^{\circledR}$ CTec2 - indicated as R4 during enzymatic hydrolysis and (B, D) - straw hydrolysed by $13 \%$ w/w enzyme dosage (Cellic ${ }^{\circ}$ CTec2 to Cellic $®$ HTec2 ratio 90:10) - indicated as R6 during enzymatic hydrolysis; unfilled triangles represent ethanol, unfilled circles represents glucose and filled circles represent xylose)

Fig. 3. Mass balance of the straw biorefinery approch, aimed at maximizing the products ((a) - straw pretreated by $1.0 \% \mathrm{H}_{2} \mathrm{SO}_{4}$ at $20 \%$ biomass loading, (b) enzymatic hydrolysis (R4) with Cellic ${ }^{\circledR}$ CTec2, (c) - enzymatic hydrolysis (R6) with 10\% Cellic ${ }^{\circledR}$ CTec2 dosage replaced by Cellic $®$ HTec2, (d) - ethanol production in Pyrex flasks, (e) - succinic acid production from liquid fraction after biomass pretreatment $\left(S_{\text {after pret. }}\right)$ at 80:20 ratio of feedstock to medium, (f) - succinic acid production from residue after ethanol fermentation without medium addition $\left(\mathrm{S}_{\mathrm{after}}\right.$ EtOH);; SA. - succinic acid; AcA - acetic acid; FA - formic acid; EtOH - ethanol 


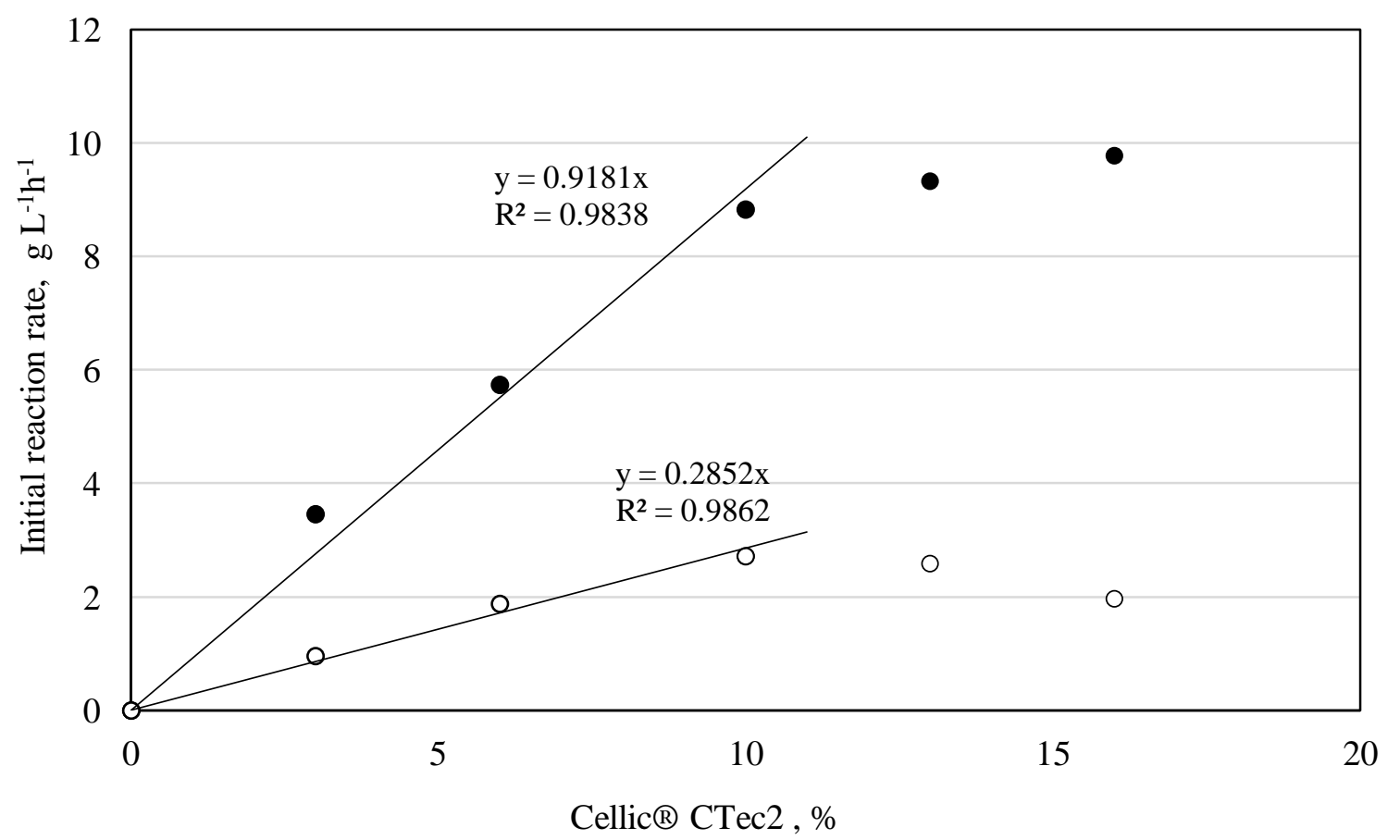

Fig. 1. 

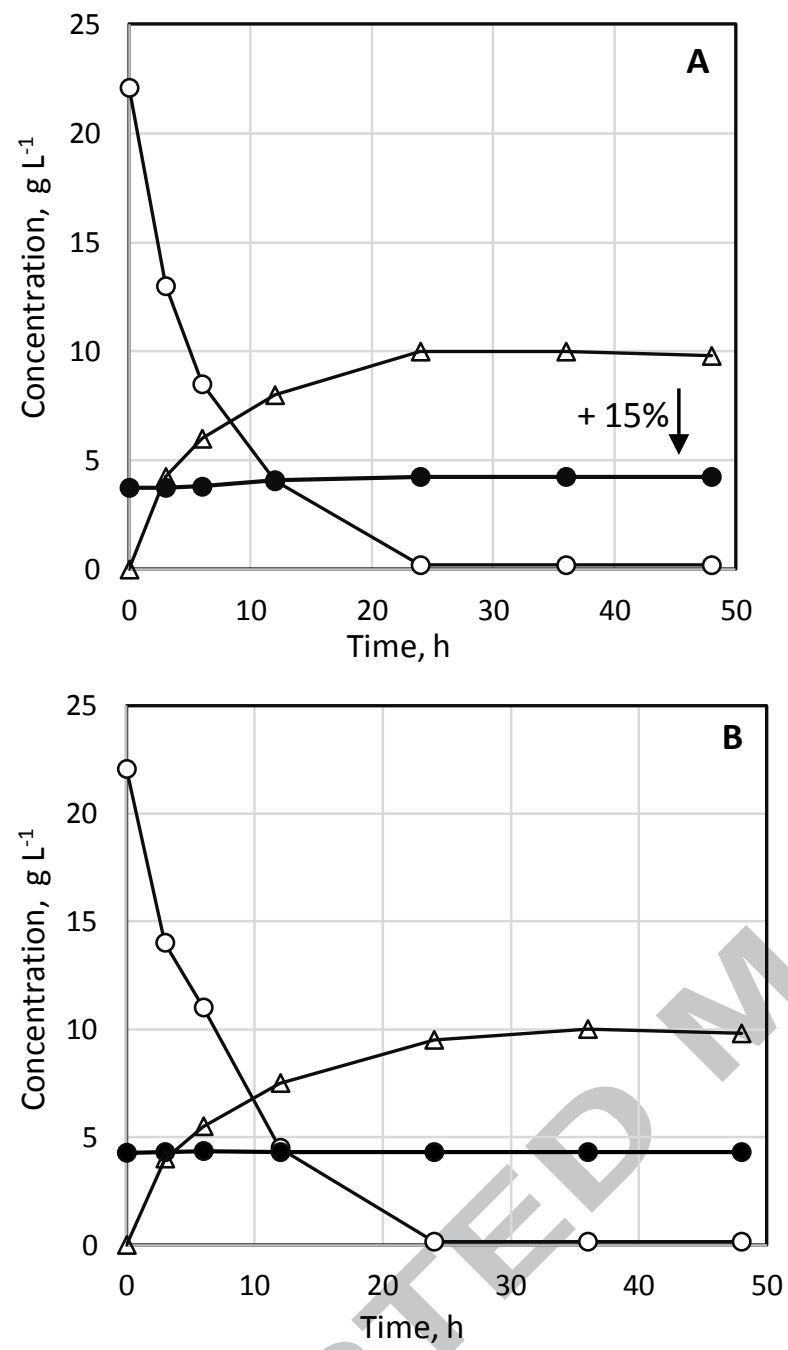

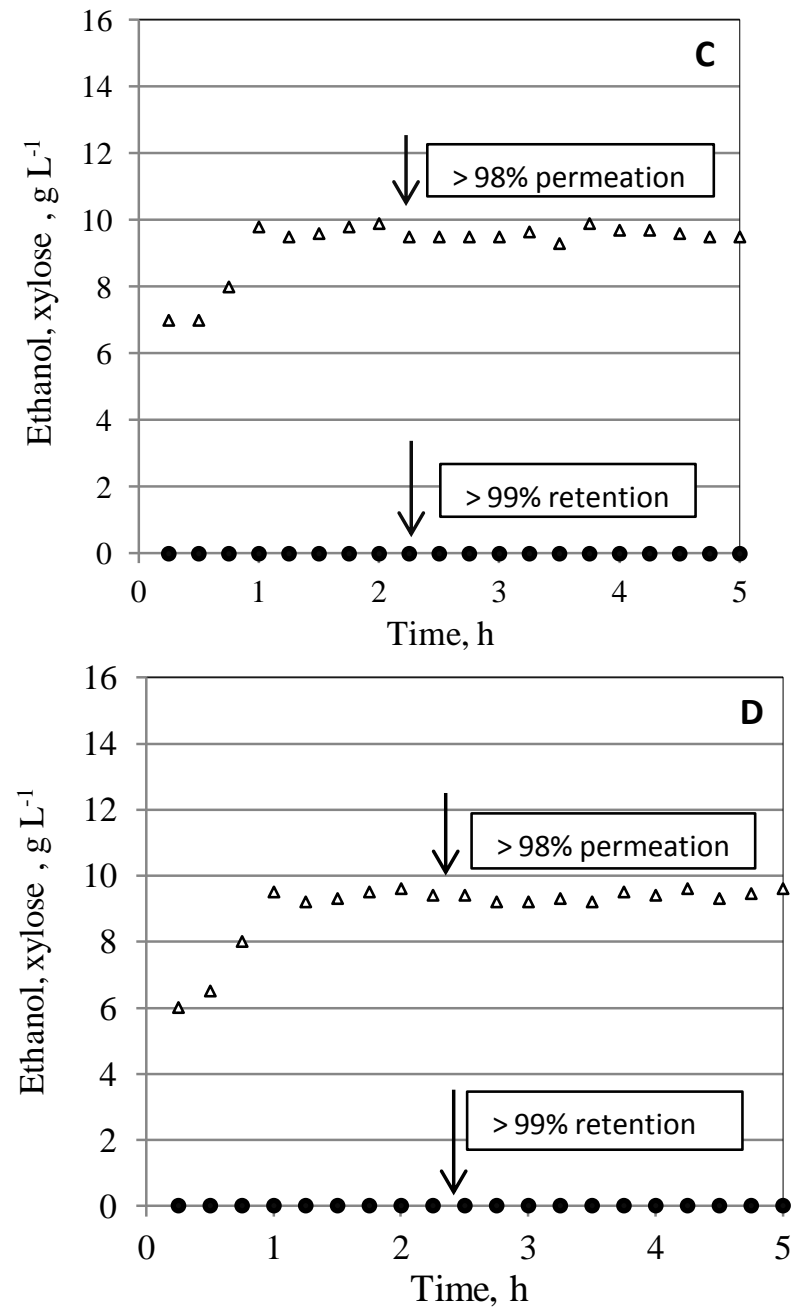

Fig. 2. 
Table 1. Fraction insoluble recovery and chemical composition of solid fraction after $\mathrm{H}_{2} \mathrm{SO}_{4}$-catalysed pretreatment of rapeseed straw (DM - dry matter, rec. $=$ recovery,

\begin{tabular}{llllllll}
\hline $\begin{array}{l}\text { Pretreatmen } \\
\mathrm{t}\end{array}$ & $\begin{array}{l}\text { Glucan, } \\
\% \mathrm{DM}\end{array}$ & $\begin{array}{l}\text { Glucan } \\
\text { rec., } \%^{\mathrm{a}}\end{array}$ & $\begin{array}{l}\text { Xylan, } \\
\% \mathrm{DM}\end{array}$ & $\begin{array}{l}\text { Xylan rec., } \\
\%^{\mathrm{a}}\end{array}$ & $\begin{array}{l}\text { Lignin, } \\
\% \mathrm{DM}\end{array}$ & $\begin{array}{l}\text { Lignin } \\
\text { rec., } \%^{\mathrm{a}}\end{array}$ & $\begin{array}{l}\text { FIS, } \\
\%^{\mathrm{b}}\end{array}$ \\
\hline Untreated & $35.5 \pm 1.8 \mathrm{c}$ & - & $18.9 \pm 0.9 \mathrm{a}$ & - & $21.7 \pm 1.6 \mathrm{c}$ & - & \\
$10 \% \mathrm{DM}$ & $54.4 \pm 1.5 \mathrm{a}$ & $95.8 \pm 2.7 \mathrm{a}$ & $6.14 \pm 0.9 \mathrm{c}$ & $18.4 \pm 3.0 \mathrm{c}$ & $33.4 \pm 2.7 \mathrm{a}$ & $96.6 \pm 2.8 \mathrm{a}$ & $62.7 \pm 0.8 \mathrm{c}$ \\
$15 \% \mathrm{DM}$ & $52.5 \pm 1.9 \mathrm{a}$ & $96.6 \pm 2.6 \mathrm{a}$ & $7.68 \pm 0.7 \mathrm{c}$ & $23.8 \pm 2.3 \mathrm{bc}$ & $33.2 \pm 2.1 \mathrm{a}$ & $99.5 \pm 2.2 \mathrm{a}$ & $64.9 \pm 1.8 \mathrm{bc}$ \\
$20 \% \mathrm{DM}$ & $52.5 \pm 1.9 \mathrm{a}$ & $98.7 \pm 2.3 \mathrm{a}$ & $8.00 \pm 0.4 \mathrm{c}$ & $25.6 \pm 1.8 \mathrm{~b}$ & $32.3 \pm 1.1 \mathrm{a}$ & $102 \pm 4.8 \mathrm{a}$ & $66.8 \pm 1.4 \mathrm{~b}$ \\
$25 \% \mathrm{DM}$ & $47.1 \pm 1.1 \mathrm{~b}$ & $96.8 \pm 2.4 \mathrm{a}$ & $10.7 \pm 0.8 \mathrm{~b}$ & $37.4 \pm 2.1 \mathrm{a}$ & $30.4 \pm 1.4 \mathrm{~b}$ & $102 \pm 5.5 \mathrm{a}$ & $72.8 \pm 1.3 \mathrm{a}$ \\
\hline
\end{tabular}

\pm standard deviation, $\mathrm{n}=4$, the same letters represent data equivalent statistically $\mathrm{p}>$ $0.05)$

a - cellulose/hemicellulose/lignin recovered in solid fractions after pretreatment and expressed as percentage related to cellulose/hemicellulose/lignin content in biomass before pretreatment, ${ }^{b}$ - FIS (water insoluble fraction) represent dry weight of solids after pretreatment and calculated as percentage of initial dry weight of slurry used for pretreatment 
Table 2. Characteristics of pretreatment liquors (DM - dry matter of biomass used for pretreatment, rec. $=$ recovery, \pm standard deviation, $n=4$, the same letters represent data

\begin{tabular}{|c|c|c|c|c|c|c|}
\hline Pretreatment & $\begin{array}{l}\text { Glucose } \\
\text { g/L }(\% \\
\left.\text { rec. }^{\text {a }}\right)\end{array}$ & $\begin{array}{l}\text { Xylose } \\
\text { g/L ( } \% \\
\left.\text { rec. }^{\text {a }}\right)\end{array}$ & $\begin{array}{l}\text { Arabinose } \\
\left.\text { g/L (\% rec. }{ }^{a}\right)\end{array}$ & $\begin{array}{l}\text { Furfural } \\
\mathrm{g} / \mathrm{L}\left(\mathrm{Y}_{\text {Furfural }}{ }^{\mathrm{b}}\right)\end{array}$ & $\begin{array}{l}\mathrm{HMF} \\
\mathrm{g} / \mathrm{L}\left(\mathrm{Y}_{\mathrm{HMF}}^{\mathrm{c}}\right)\end{array}$ & $\begin{array}{l}\text { Acetic acid } \\
\mathrm{g} / \mathrm{L}\left(\%^{\mathrm{d}}\right)\end{array}$ \\
\hline $10 \% \mathrm{DM}$ & $\begin{array}{l}0.62 \pm 0.1 \mathrm{a} \\
(0.95 \pm 0.1) \mathrm{a}\end{array}$ & $\begin{array}{l}16.6 \pm 1.2 \mathrm{c} \\
(49.5 \pm 3.1) \mathrm{a}\end{array}$ & $\begin{array}{l}2.11 \pm 0.3 \mathrm{ab} \\
(55.9 \pm 5.5 \mathrm{ab})\end{array}$ & $\begin{array}{l}0.27 \pm 0.07 a \\
(1.05 \pm 0.3 a)\end{array}$ & $\begin{array}{l}0.13 \pm 0.04 a \\
(0.27 \pm 0.1 a)\end{array}$ & $\begin{array}{l}2.60 \pm 0.4 b \\
(8.35 \pm 1.6 a)\end{array}$ \\
\hline $15 \% \mathrm{DM}$ & $\begin{array}{l}0.72 \pm 0.2 \mathrm{a} \\
(0.72 \pm 0.2) \mathrm{a}\end{array}$ & $\begin{array}{l}24.4 \pm 2.0 \mathrm{~b} \\
(46.7 \pm 2.8) \mathrm{a}\end{array}$ & $\begin{array}{l}2.23 \pm 0.1 \mathrm{ab} \\
(58.1 \pm 4.3 \mathrm{ab})\end{array}$ & $\begin{array}{l}0.42 \pm 0.05 a \\
(1.06 \pm 0.1 a)\end{array}$ & $\begin{array}{l}0.18 \pm 0.05 a \\
(0.25 \pm 0.1 a)\end{array}$ & $\begin{array}{l}3.55 \pm 0.3 b \\
(7.83 \pm 0.9 a)\end{array}$ \\
\hline $20 \%$ DM & $\begin{array}{l}0.50 \pm 0.1 \mathrm{a} \\
(0.37 \pm 0.1) \mathrm{b}\end{array}$ & $\begin{array}{l}31.8 \pm 1.2 \mathrm{a} \\
(44.0 \pm 3.2) \mathrm{a}\end{array}$ & $\begin{array}{l}2.46 \pm 0.1 \mathrm{a} \\
(62.5 \pm 4.9 \mathrm{a})\end{array}$ & $\begin{array}{l}0.53 \pm 0.08 a \\
(1.11 \pm 0.1 a)\end{array}$ & $\begin{array}{l}0.23 \pm 0.11 a \\
(0.24 \pm 0.1 a)\end{array}$ & $\begin{array}{l}5.17 \pm 0.7 a \\
(7.86 \pm 1.1 a)\end{array}$ \\
\hline $25 \% \mathrm{DM}$ & $\begin{array}{l}0.47 \pm 0.1 \mathrm{a} \\
(0.21 \pm 0.1) \mathrm{b}\end{array}$ & $\begin{array}{l}25.2 \pm 2.3 b \\
(28.0 \pm 1.5) b\end{array}$ & $\begin{array}{l}1.96 \pm 0.1 b \\
(49.1 \pm 4.4 b)\end{array}$ & $\begin{array}{l}0.51 \pm 0.09 a \\
(0.79 \pm 0.2 a)\end{array}$ & $\begin{array}{l}0.18 \pm 0.11 a \\
(0.15 \pm 0.1 a)\end{array}$ & $\begin{array}{l}3.27 \pm 0.8 b \\
(4.39 \pm 0.8 b)\end{array}$ \\
\hline
\end{tabular}

equivalent statistically $\mathrm{p}>0.05)$

a - component recovery (glucose, xylose, arabinose) expressed as a percentage of cellulose or hemicellulose content in biomass before pretreatment, ${ }^{b}$ - furfural yield calculated according to Eq. (1), ${ }^{c}$ - HMF yield calculated according to Eq. (2), ${ }^{\mathrm{d}}$-degree of acetylation, calculated as percentage of xylan content in biomass dry matter 
Table 3. Effectiveness of enzymatic hydrolysis and overall sugar yields after pretreatment and enzymatic hydrolysis ( \pm standard deviation, $n=4$, the same letters represent data equivalent statistically $\mathrm{p}>0.05$ ).

\begin{tabular}{|c|c|c|c|c|c|c|c|c|}
\hline \multicolumn{6}{|c|}{ Enzymatic hydrolysis } & \multicolumn{3}{|c|}{ Pretreatment + Enzymatic hydrol } \\
\hline $\begin{array}{l}\text { Glucose, } \\
\mathrm{g} \mathrm{L}^{-1}\end{array}$ & $\begin{array}{l}\text { Glucose } \\
\text { yield, } \%^{\text {a }}\end{array}$ & $\begin{array}{l}\text { Xylose, } \\
\mathrm{g} \mathrm{L}^{-1}\end{array}$ & $\begin{array}{l}\text { Xylose yield, } \\
\%^{\mathrm{a}}\end{array}$ & $\begin{array}{l}\text { Total } \\
\text { conc., g/L }\end{array}$ & $\begin{array}{l}\text { Total, } \\
\text { Yield }^{\mathrm{a}}, \%\end{array}$ & $\begin{array}{l}\text { Total }_{\mathrm{Glu}} \\
\text { (Eq.3), \% }\end{array}$ & $\begin{array}{l}\text { Total }{ }_{\text {Xyl. }} . \\
\text { (Eq.4), \% }\end{array}$ & $\begin{array}{l}\text { Total }_{\text {Sug }} \\
\text { (Eq.5), }\end{array}$ \\
\hline $6.42 \pm 0.3 \mathrm{e}$ & $32.4 \pm 1.5 \mathrm{e}$ & $3.07 \pm 0.1 \mathrm{~d}$ & $28.6 \pm 1.1 \mathrm{f}$ & $9.50 \pm 0.3 \mathrm{e}$ & $28.1 \pm 0.8 \mathrm{e}$ & $32.6 \pm 1.5 \mathrm{e}$ & $20.7 \pm 0.8 \mathrm{~d}$ & \\
\hline $12.9 \pm 0.4 \mathrm{f}$ & $44.1 \pm 1.4 \mathrm{~d}$ & $2.27 \pm 0.2 \mathrm{e}$ & $49.9 \pm 3.8 \mathrm{e}$ & $15.1 \pm 0.6 \mathrm{~d}$ & $44.9 \pm 1.7 \mathrm{~d}$ & $48.8 \pm 1.6 \mathrm{~d}$ & $62.3 \pm 3.7 \mathrm{c}$ & \\
\hline $16.6 \pm 0.4 \mathrm{~d}$ & $56.8 \pm 1.5 \mathrm{c}$ & $2.92 \pm 0.2 \mathrm{~d}$ & $64.2 \pm 3.4 \mathrm{~d}$ & $19.5 \pm 0.4 \mathrm{c}$ & $57.8 \pm 1.1 \mathrm{c}$ & $62.8 \pm 1.6 \mathrm{c}$ & $66.9 \pm 4.3 \mathrm{bc}$ & \\
\hline $19.2 \pm 0.5 c$ & $65.8 \pm 1.7 \mathrm{~b}$ & $3.61 \pm 0.1 \mathrm{c}$ & $79.4 \pm 3.1 \mathrm{c}$ & $22.8 \pm 0.4 b$ & $67.6 \pm 1.1 \mathrm{~b}$ & $72.6 \pm 1.9 b$ & $71.8 \pm 2.3 \mathrm{ab}$ & $72.3 \pm$ \\
\hline $23.2 \pm 0.5 \mathrm{ab}$ & $79.6 \pm 1.8 \mathrm{a}$ & $4.05 \pm 0.1 b$ & $88.7 \pm 3.0 \mathrm{~b}$ & $27.2 \pm 0.7 \mathrm{a}$ & $80.9 \pm 2.0 \mathrm{a}$ & $87.7 \pm 2.0 \mathrm{a}$ & $74.9 \pm 4.0 \mathrm{ab}$ & $83.3 \pm$ \\
\hline $23.0 \pm 0.5 \mathrm{ab}$ & $79.0 \pm 1.9 \mathrm{a}$ & $4.06 \pm 0.2 b$ & $89.4 \pm 3.5 b$ & $27.1 \pm 0.5 \mathrm{a}$ & $80.4 \pm 1.4 a$ & $87.1 \pm 2.1 \mathrm{a}$ & $75.0 \pm 2.2 \mathrm{ab}$ & $82.9 \pm$ \\
\hline $23.3 \pm 0.6 \mathrm{a}$ & $80.0 \pm 2.0 \mathrm{a}$ & $4.47 \pm 0.1 \mathrm{a}$ & $98.3 \pm 2.3 \mathrm{a}$ & $27.8 \pm 0.6 \mathrm{a}$ & $82.5 \pm 1.9 \mathrm{a}$ & $88.9 \pm 2.3 \mathrm{a}$ & $77.9 \pm 3.8 \mathrm{a}$ & $84.6 \pm$ \\
\hline $22.0 \pm 0.5 b$ & $75.3 \pm 1.7 \mathrm{a}$ & $4.52 \pm 0.1 \mathrm{a}$ & $99.5 \pm 2.0 \mathrm{a}$ & $26.5 \pm 0.4 a$ & $78.6 \pm 1.3 \mathrm{a}$ & $83.0 \pm 1.9 \mathrm{a}$ & $78.3 \pm 2.9 \mathrm{a}$ & $81.4 \pm 1$ \\
\hline
\end{tabular}

${ }^{a}$ - glucose or/and xylose released during enzymatic hydrolysis and calculated as percentage of glucan or/and xylan present in the material before enzymatic hydrolysis, R0: untreated material, R1-7: pretreated material and, \% w/w - enzymatic cocktails weight expressed as dry matter of substrate used during experiment, R0: enzyme dosage of $13 \%$ (Cellic ${ }^{\circledR}$ CTec2 to Cellic ${ }^{\circledR}$ HTec2 ratio 80:20), R1-5: Cellic ${ }^{\circledR}$ CTec2 (R1: 3\%, R2: 6\%, R3: 10\%, R4: 13\%, R5: 16\%), R6: enzyme total dosage of 13\% (Cellic $®$ CTec2 to Cellic® HTec2 ratio 90:10), R7: enzyme total dosage of 13\% (Cellic® CTec2 to Cellic® HTec2 ratio 80:20). 